\title{
Pengaruh Perputaran Modal Kerja Terhadap Profitabilitas: Studi Kasus Perusahaan Makanan dan Minuman yang Terdaftar di Bursa Efek Indonesia 2014-2018
}

\author{
Ahmad Faishol, Moh Yusril Efendi \\ Fakultas Ekonomi, Universitas Islam Lamongan \\ Email authors: ahmad.faishol1010@gmail.com/efendyyusriel17@gmail.com
}

\begin{abstract}
ABSTRAK
Penelitian ini bertujuan untuk mengetahui tentang: (1) Pengaruh Perputaran Modal Kerja terhadap Profitabilitas. (2) Pengaruh Perputaran Modal Kerja terhadap Profitabilitas.Metode penelitian yang digunakan dalam penelitian ini adalah kuantitatif. Populasi penelitian ini adalah perusahaan Makanan dan Minuman yang terdaftar di Bursa Efek Indonesia tahun 2014 -2018. Sampel dari penelitian ini ada 13 perusahaan Makanan dan Minuman. Analisis data yang digunakan dalam penelitian ini adalah dengan metode deskriptif. Alat analisis datanya yaitu Asumsi Klasik dan Uji Hipotesis.Hasil penelitian menunjukkan (1) Perputaran Modal Kerja tidak berpengaruh signifikan secara parsial terhadap Profitabilitas. (2) Perputaran Modal Kerja berpengaruh signifikan secara simultan terhadap Profitabilitas.
\end{abstract}

Kata Kunci: Perputaran Modal Kerja, Profitabilitas.

\section{PENDAHULUAN}

Perkembangan perekonomian semua perusahaan mengalami persaingan bisnis yang semakin ketat.Bursa Efek Indonesia merupakan suatu pasar modal yang dapat dijadikan alternatif pendanaan bagi semua sektor perusahaan di Indonesia terutama pada sektor makanan dan minuman. Industri makanan dan minuman berkembang dengan pesat dibanding dengan industri yang lain. Industri makanan dan minuman memperoleh peluang untuk terus tumbuh bahkan saat krisis ekonomi global melanda pada tahun 2010 (Indah Ayu Felany dan Saparila Worokinasih, 2018:121).Industri makanan dan minuman merupakan subsektor dari industri manufaktur yang memiliki peranan dalam perkembangan perekonomian di Indonesia.

Sub Sektor makanan dan minuman turut mengalami penurunan akibat krisis tahun 2010 (Indah Ayu Felany dan Saparila Worokinasih, 2018:121). Pada tahun 2015 menunjukan pertumbuhan industri makanan dan minuman mengalami perlambatan dibandingkan pada tahun 2014, kemudian pada tahun 2016 pertumbuhan industri makanan dan minuman mengalami kenaikan. Hal tersebut disebabkan oleh faktor permintaan pada sektor ini tetap tinggi dan dapat bertahan tidak bergantung pada bahan baku impor karena lebih banyak menggunakan bahan baku domestik (Indah Ayu Felany dan Saparila Worokinasih, 2018:121). Pertumbuhan industri makanan dan 
minuman yang mengalami fluktuasi ini membuat para produsen produk makanan dan minuman dituntut agar dapat terus meningkatkan labanya atau profitabilitas.

Untuk mengukur tingkat keuntungan suatu perusahaan dalam memperoleh laba dapat diukur dengan menggunakan rasio profitabilitas. Menurut Kasmir (2017:110) rasio Profitabilitas merupakan rasio untuk menilai kemampun perusahaan dalam mencari keuntungan. Terdapat beberapa alat ukur yang digunakan dalam mengukur tingkat profitabilitas, dalam penelitian ini profitabilitas akan di ukur dengan menggunakan return on assets (ROA). Tinggi rendahnya profitabilitas dipengaruhi banyak faktor seperti modal kerja dan likuiditas (Novia Dwiyanthi dan Gede Merta Sudiartha, 2017:4831).

Salah satu faktor terpenting dalam produksi adalah modal kerja yang digunakan oleh perusahaan untuk membiayai operasi perusahaan demi kelangsungan hidup perusahaan dan dana tersebut akan terus berputar selama perusahaan masih berjalan adalah perputaran modal kerja. Perputaran modal kerja dimulai dengan pada saat kas diinvestasikan dalam komponen modal kerja sampai saat kembali lagi menjadi kas.Semakin cepat perputaran modal kerja menunjukkan bahwa semakin efektif penggunaan modal kerja yang berdampak pada meningkatnya profitabilitas perusahaan (Riny Widhi Astuti, 2017:11).

Perusahaan pada umumnya harus mempertahankan jumlah modal kerja yang menguntungkan yaitu pada jumlah aktiva lancar yang harus lebih besar dibandingkan dengan jumlah kewajiban lancar. Hal ini dimaksudkan sebagai jaminan kemampuan perusahaan untuk membayar kewajiban-kewajiban jangka pendeknya atau likuiditasnya. Menurut Munawir dalam Bunga Asri Novita dan Sofie (2015:15) mengemukakan bahwa likuiditas adalah kemampuan suatu perusahaan untuk memenuhi kewajiban keuangannya yang segera harus dipenuhi, atau kemampuan suatu perusahaan untuk memenuhi kewajiban keuangannya pada saat ditagih.

\section{METODE PENELITIAN}

Jenis penelitian yang digunakan dalam penelitian ini adalah penelitian kuantitatif. Menurut Sugiyono (2017: 23) Penelitian kuantitatif adalah data yang berbentuk angka atau kualitatif yang diangkakan (skoring).

Populasi dalam penelitian ini adalah perusahaan Makanan dan Minuman yang terdaftar di Bursa Efek Indonesia tahun 2014-2018. Sampel dalam penelitian ini adalah 13 perusahaan Makanan dan Minuman. Teknik pengambilan sampel dalam penelitian ini dilakukan dengan metode purposive sampling.

Operasional variabel dalam penelitian ini terdiri dari Working Capital Turnover dan Current Ratio yang merupakan variabel independen dan Return On Asset (ROA) sebagai variabel dependen. 
Teknik analisis data dalam penelitian ini menggunakan uji asumsi klasik dan uji hipotesis yang terdiri dari analisis regresi linier berganda, koefisien determinasi $\left(R^{2}\right)$, uji t dan uji $\mathrm{f}$.

\section{TEMUAN DAN PEMBAHASAN}

\section{Analisis Deskriptif}

Tabel 1. Analisis Deskriptif

\begin{tabular}{lccccc}
\hline & N & Minimum & Maximum & Mean & Std. Deviation \\
\hline Perputaran Modal Kerja & 65 & $-14,92$ & 1893,95 & 75,0487 & 311,87194 \\
Likuiditas & 65 &, 51 & 8,64 & 2,2681 & 1,70234 \\
Profitabilitas & 65 &, 01 &, 53 &, 1094 &, 10425 \\
Valid N (listwise) & 65 & & & & \\
\hline
\end{tabular}

Sumber: Hasil olah data SPSS

Berdasarkan hasil uji Statistik Deskriptif diatas dapat diketahui bahwa :

1. Hasil tersebut menunjukan bahwa besar Perputaran Modal Kerja pada perusahaan Makanan dan Minuman yang menjadi sampel penelitian ini berkisar antara -14,92 sampai 1893,95 dengan rata-rata 311,87194.

2. Hasil tersebut menunjukan bahwa profitabilitas pada pada perusahaan Makanan dan Minuman yang menjadi sampel penelitian ini berkisar antara 0,01 sampai 0,53 dengan rata-rata 0,10425 .

\section{Uji Normalitas}

Tabel 2. Hasil Uji Normalitas

\begin{tabular}{llr}
\hline & & $\begin{array}{r}\text { Unstandardized } \\
\text { Residual }\end{array}$ \\
\hline $\mathrm{N}$ & & 50 \\
Normal Parameters ${ }^{\mathrm{a}, \mathrm{b}}$ & Mean &, 0000000 \\
& Std. Deviation &, 03390329 \\
Most Extreme & Absolute &, 102 \\
Differences & Positive &, 096 \\
& Negative &,- 102 \\
Test Statistic & &, 102 \\
Asymp. Sig. (2-tailed) & &, $200^{\mathrm{c}, \mathrm{d}}$ \\
\hline
\end{tabular}

Sumber : Hasil Olah Data SPSS

Berdasarkan Tabel 2. hasil uji normalitas menggunakan uji Kolmogorov Smirnov , ditunjukan hubungan normal. Berdasarkan hasil output SPSS, besar nilai K-S untuk signifikasi 0,200 pada Asymp. Sig. (2-tailed) jauh diatas $\alpha=0,05$. Hal ini menunjukan bahwa data terdistribusi secara normal. 


\section{Uji Multikolinieritas}

\begin{tabular}{llcc}
\multicolumn{4}{c}{ Tabel 3. Hasil Uji Multikolinieritas } \\
\hline \multirow{2}{*}{ Model } & \multicolumn{2}{c}{ Collinearity Statistics } \\
\cline { 2 - 3 } & Tolerance & VIF \\
\hline $1 \quad$ (Constant) &, 671 & 1,490 \\
& Perputaran Modal Kerja &, 671 & 1,490 \\
\multicolumn{2}{l}{ Likuiditas } &
\end{tabular}

Sumber : Hasil Olah Data SPSS

Berdasarkan hasil pengujian dari table diatas dapat diketahui bahwa kedua variabel bebas tersebut mempunyai nilai tolerance lebih dari 0,10 yaitu 0,671 dan nilai VIF kurang dari 10,00 yaitu 1,490. Maka dapat disimpulkan bahwa tidak terjadi multikolinieritas antar variabel bebas yaitu perputaran modal kerja dan likuiditas.

\section{Uji Heteroskedastisitas}

Tabel 4. Hasil Uji Heteroskedastisitas

\begin{tabular}{lrrrrrr}
\hline & \multicolumn{2}{c}{$\begin{array}{l}\text { Unstandardized } \\
\text { Coefficients }\end{array}$} & $\begin{array}{c}\text { Standardized } \\
\text { Coefficients }\end{array}$ & & \\
\cline { 2 - 4 } Model & B & Std. Error & Beta & & Sig. \\
\hline 1 (Constant) &, 024 &, 012 & & 1,997 &, 052 \\
$\quad$ Perputaran Modal Kerja &, 000 &, 000 &,- 135 &,- 775 &, 442 \\
$\quad$ Likuiditas &, 002 &, 004 &, 086 &, 491 &, 626 \\
\hline
\end{tabular}

Sumber : Hasil Olah Data SPSS

Berdasarkan pengujian yang telah dilakukan pada table diatas dapat diketahui bahwa hasil perhitungan dari masing-masing menunjukan level sig $>\alpha=0,05$, yaitu 0,442 untuk variabel Perputaran Modal Kerja, dan 0,626 untuk variabel Likuiditas. Sehingga dapat disimpulkan bahwa pada penelitian ini bebas uji heteroskedastisitas dan layak untuk diteliti.

\section{Uji Autokolerasi}

Tabel 5. Hasil Uji Autokolerasi

\begin{tabular}{ccrrrr}
\hline Model & $\mathrm{R}$ & $\begin{array}{c}\mathrm{R} \\
\text { Square }\end{array}$ & $\begin{array}{c}\text { Adjusted R } \\
\text { Square }\end{array}$ & $\begin{array}{c}\text { Std. Error of } \\
\text { the Estimate }\end{array}$ & $\begin{array}{c}\text { Durbin- } \\
\text { Watson }\end{array}$ \\
\hline 1 &, $544^{\mathrm{a}}$ &, 296 &, 266 &, 0346171 & 1,672 \\
\hline
\end{tabular}

Sumber : Hasil Olah Data SPSS

Dasar pengambilan keputusan pada uji Durbin Waston yaitu du $<\mathrm{d}<4$-du, sehingga dapat dijelaskan bahwa nilai Durbin Waston(d) sebesar 1,672 lebih besar dari batas atas (du) yakni 1,628 dan kurang dari (4-du) yaitu $4-1,628=2,372$. Maka 
sebagaimana dari dasar pengambilan keputusan uji Durbin Waston di atas, dapat disimpulkan bahwa tidak terjadi autokolerasi antara variabel independen.

\section{Analisis Regresi Linier Berganda}

Tabel 6. Hasil Analisis Regresi Linier Berganda

\begin{tabular}{llr}
\hline & & \multicolumn{2}{c}{$\begin{array}{c}\text { Unstandardized } \\
\text { Coefficients }\end{array}$} \\
\cline { 3 - 3 } Model & & \multicolumn{2}{c}{ B } \\
\hline 1 & (Constant) &, 044 \\
& Perputaran Modal Kerja & -001 \\
& Likuiditas &, 019 \\
\hline
\end{tabular}

Sumber : Hasil Olah Data SPSS

Berdasarkan hasil perhitungan pada tabel diatas, diperoleh bentuk persamaan regresi linier berganda sebagai berikut :

$$
\mathrm{Y}=0,044-0,001 \mathrm{X}_{1}+0,019 \mathrm{X}_{2}+\mathrm{e}
$$

Dari persamaan regresi linier berganda diatas, nilai masing - masing koefisien regresi variabel dependen dapat memberikan gambaran bahwa : Koefisien regresi variabel Perputaran Modal Kerja sebesar - 0,001 yang menggambarkan bahwa Perputaran Modal Kerja mempunyai pengaruh negatif terhadap besarnya profitabilitas perusahaan, artinya Perputaran Modal Kerja memiliki hubungan yang tidak searah dengan Profitabilitas. Hal ini menunjukkan bahwa semakin tinggi Perputaran Modal Kerja maka Profitabilitas perusahaan akan menurun dan sebaliknya.

\section{Uji Koefesien Determinasi $\left(R^{2}\right)$}

\begin{tabular}{lcrrr} 
& \multicolumn{4}{c}{ Tabel 7. Uji Koefisiensi Determinasi $\left(\mathrm{R}^{2}\right)$} \\
\hline Model & $\mathrm{R}$ & $\mathrm{R}$ Square & $\begin{array}{c}\text { Adjusted } \mathrm{R} \\
\text { Square }\end{array}$ & $\begin{array}{r}\text { Std. Error of } \\
\text { the Estimate }\end{array}$ \\
\hline 1 &, $544^{\mathrm{a}}$ &, 296 &, 266 &, 0346171 \\
\hline
\end{tabular}

Sumber : Hasil Olah Data SPSS

Berdasarkan tabel diatas diperoleh nilai koefisien determinasi yang ditunjukan dari nilai $R$ Square $\left(R^{2}\right)$ sebesar 0,296 . Hal ini menunjukan bahwa pengaruh variabel independen yaitu Perputaran Modal Kerja dan Likuiditas secara simultan terhadap variabel dependen yaitu Profitabilitas adalah sebesar 29,6\% 


\section{Uji t-Statistik (Parsial)}

Tabel 8. Hasil Uji t-Statistik (Parsial)

\begin{tabular}{|c|c|c|c|c|c|}
\hline \multirow[b]{2}{*}{ Model } & \multicolumn{2}{|c|}{$\begin{array}{c}\text { Unstandardized } \\
\text { Coefficients }\end{array}$} & \multirow{2}{*}{$\begin{array}{c}\begin{array}{c}\text { Standardized } \\
\text { Coefficients }\end{array} \\
\text { Beta }\end{array}$} & \multirow[b]{2}{*}{$t$} & \multirow[b]{2}{*}{ Sig. } \\
\hline & $\mathrm{B}$ & $\begin{array}{l}\text { Std. } \\
\text { Error }\end{array}$ & & & \\
\hline 1 (Constant) & 044 & ,018 & & 2,471 & ,017 \\
\hline Perputaran Modal Kerja &,- 001 & ,001 &,- 113 &,- 758 & ,452 \\
\hline Likuiditas & ,019 & ,006 & ,471 & 3,153 & ,003 \\
\hline
\end{tabular}

Sumber : Hasil Olah Data SPSS

Dalam penelitian ini dilakukan uji t dengan nilai df $(n-k-1)$ yaitu $(50-2=1=47)$ pada $\alpha=5 \%$ adalah sebesar 2,012.

\section{Hipotesis $1\left(H_{1}\right)$}

Berdasarkan hasil pengolahan data tabel diatas menunjukkan bahwa variabel Perputaran Modal Kerja diperoleh nilai signifikan yang berada lebih besar dari nilai signifikan umumnya yaitu $0,452>0,05$. Pada tingkat signifikan $\alpha=5 \%$ dan tabel dengan df (47) adalah sebesar 2,012, dan pada tabel diatas diperoleh nilai thitung lebih kecil dari tabelyaitu $-0,758<2,012$. Sehingga dapat disimpulkan bahwa variabel Perputaran Modal Kerja tidak berpengaruh signifikan terhadap Profitabilitas, maka dari itu hipotesis pertama $\mathrm{H}_{1}$ ditolak.

\section{Uji F-Statistik (Simultan)}

Tabel 9. Hasil Uji F-Statistik (Simultan)

\begin{tabular}{|c|c|c|c|c|c|c|}
\hline \multicolumn{2}{|c|}{ Model } & $\begin{array}{l}\text { Sum of } \\
\text { Squares }\end{array}$ & \multirow{2}{*}{$\frac{\mathrm{df}}{2}$} & \multirow{2}{*}{$\begin{array}{c}\begin{array}{c}\text { Mean } \\
\text { Square }\end{array} \\
, 012\end{array}$} & \multirow{2}{*}{$\frac{F}{9,876}$} & \multirow{2}{*}{$\frac{\text { Sig. }}{, 000^{\mathrm{b}}}$} \\
\hline 1 & Regression & ,024 & & & & \\
\hline & Residual & ,056 & 47 & ,001 & & \\
\hline & Total & , 080 & 49 & & & \\
\hline
\end{tabular}

Sumber : Hasil Olah Data SPSS

Dalam penelitian ini dilakukan uji $\mathrm{F}$ dengan nilai df1 $(\mathrm{k}-1)$ yaitu $(2-1=1)$,dan df2 $(n-k)$ yaitu $(50-2=48)$ maka nilai $F_{\text {tabel }}$ untuktaraf signifikansi 5\% adalah sebesar 4,04. Dan dari hasil perhitungan tabel diatas dapat diperoleh nilai signifikan yang berada lebih kecil dari nilai signifikan umumnya yaitu $0,000<0,05$. Untuk signifikansi 0,05 dan $F_{\text {tabel }}$ sebesar 4,04 pada tabel diatas diperoleh nilai $F_{\text {hitung }}$ lebih besar dari Ftabelyaitu 9,876 > 4,04. Sehingga dapat disimpulkan bahwa secara simultan dengan taraf signifikansi $5 \%$ terdapat pengaruh signifikan antara variabel Perputaran Modal Kerja dan Likuiditas terhadap Profitabilitas. Hal ini menunjukkan bahwa $\mathrm{H}_{3}$ diterima. 


\section{PEMBAHASAN}

\section{Pengaruh Perputaran Modal Kerja Terhadap Profitabilitas}

Berdasarkan hasil analisis statistik menggunakan uji $\mathrm{T}$, nilai signifikasi sebesar 0,452 > 0,05 dan nilai thitung lebih kecil dari tabel yaitu $-0,758<2,012$ menunjukkan bahwa Perputaran Modal Kerja tidak berpengaruh terhadap Profitabilitas. maka dari itu hipotesis pertama $\mathrm{H}_{1}$ ditolak.

Variabel perputaran modal kerja sebesar $-0,001$ dan bertanda negatif, hal ini berarti bahwa setiap perubahan 1 satuan pada kenaikan perputaran modal kerja akan menurunkan profitabilitas sebesar -0,001 dengan arah yang berlawanan. Semakin tinggi perputaran modal kerja maka akan semakin menurun profitabilitasnya. Hasil penelitian ini sejalan dengan penelitian yang dilakukan oleh Burhanudin (2017), dan Siti Rohmawati (2017) dimana Perputaran Modal Kerja secara parsial tidak berpengaruh terhadap Profitabilitas. Disamping itu hasil penelitian ini tidak sesuai dengan penelitian yang dilakukan oleh Riny Widhi Astuti (2017) yang mengemukakan bahwa Semakin cepat perputaran modal kerja menunjukkan bahwa semakin efektif penggunaan modal kerja yang berdampak pada meningkatnya profitabilitas perusahaan.

\section{Pengaruh Perputaran Modal Kerja Terhadap Profitabilitas}

Hasil analisis penelitian ini menunjukkan bahwa Perputaran Modal Kerja berpengaruh signifikan secara simultan terhadap profitabilitas perusahaan makanan dan minuman yang terdaftar di Bursa Efek Indonesia (BEI). Hal ini dibuktikan dengan nilai nilai sig $<0,05$ atau Fhitung $>$ Ftabel yaitu nilai signifikansi 0,000 $<0,05$, dan nilai Fhitung lebih besar dari $F_{\text {tabel }}$ yaitu 9,876 $>4,04$. Artinya terbukti bahwa pengaruh variabel Perputaran Modal Kerja (X1) secara simultan terhadap profitabilitas (Y) adalah signifikan. Besarnya Ajusted $\mathrm{R}^{2}$ adalah 0,296 artinya 29,6\% variabel profitabilitas dijelaskan oleh Perputaran Modal Kerja (X1) secara simultan dan sisanya sebesar $70,4 \%$ dijelaskan oleh variabel lain yang tidak dimasukan dalam penelitian ini.

\section{Kesimpulan}

\section{KESIMPULAN DAN SARAN}

Berdasarkan hasil analisis data dan pembahasan yang sudah diuraikan, dapat disimpulkan sebagai berikut :

1. Perputaran Modal Kerja tidak berpengaruh signifikan terhadap Profitabilitas. Hal ini dibuktikan dengan nilai signifikasi sebesar 0,452 >0,05 dan nilai thitung lebih kecil dari tabel yaitu $-0,758<2,012$. Variabel perputaran modal kerja sebesar $-0,001$ dan bertanda negatif, hal ini berarti bahwa setiap perubahan 1 satuan pada kenaikan perputaran modal kerja akan menurunkan profitabilitas sebesar -0,001 dengan arah yang berlawanan. Semakin tinggi perputaran modal kerja maka akan semakin menurun profitabilitasnya. 
2. Perputaran Modal Kerja berpengaruh signifikan secara simultan terhadap Profitabilitas. Hal ini dibuktikan dengan nilai nilai sig $<0,05$ atau $F_{\text {hitung }}>F_{\text {tabel }}$ yaitu nilai signifikansi 0,000<0,05, dan nilai Fhitung lebih besar dari Ftabel yaitu 9,876 $>4,04$. Nilai koefisien determinasi yang ditunjukan dari nilai $R$ Square $\left(R^{2}\right)$ sebesar 0,296. Hal ini menunjukan bahwa 29,6\% dari Profitabilitas dapat dijelaskan oleh variabel independen yaitu Perputaran Modal Kerja.

\section{Saran}

1. Bagi Perusahaan

Bagi pihak manajemen perusahaan Makanan dan Minuman yang tergabung dalam Bursa Efek Indonesia (BEI) diharapkan untuk lebih memperhatikan dalam pengelolaan perputaran modal kerja terhadap kegiatan perusahaan dalam memperoleh laba untuk keberlangsungan hidup perusahaan.

2. Bagi Peneliti Selanjutnya

Untuk penelitian selanjutnya diharapkan dapat mengembangkan variabel penelitian, mengurangi kekurangan yang terjadi dan dapat menjelaskan lebih menyeluruh tentang penelitiannya.Sampel penelitian ini hanya mencakup 13 perusahaan Makanan dan Minuman yang terdaftar di Bursa Efek Indonesia (BEI) menunjukkan keterbatasan penelitian. Oleh karena itu peneliti lain disarankan untuk menggunakan sampel perusahaan dengan jumlah yang lebih besar, atau juga menerapkan pada perusahaan selain perusahaan Makanan dan Minuman.

3. Bagi Universitas

Dapat digunakan untuk refernsi pada penelitian selanjutnya dan memberikan sumbangan pemikiran serta dapat menambah pengetahuan.

\section{DAFTAR PUSTAKA}

Annisa, Anya Riana. 2019. Pengaruh Perputaran Modal Kerja, Pertumbuhan Penjualan, dan Likuiditas terhadap Profitabilitas pada Perusahaan Retail yang terdaftar di Bursa Efek Indonesia. Jurnal Riset Manajemen Sains Indonesia.Vol. 10, No. 1.

Astuti, Riny Widhi. 2017. Pengaruh Perputaran Modal Kerja, Perputaran Kas, Perputaran Piutang, Perputaran Persediaan terhadap Profitabilitas pada Perusahaan Manufaktur Sektor Industri Barang Konsumsi yang Terdaftar di Bursa Efek Indonesia Periode 2013-2015. Skripsi. Surakarta: Universitas Muhammadiyah Surakarta.

Burhanudin. 2017. Pengaruh Struktur Modal, Perputaran Modal Kerja terhadap Profitabilitas: Studi Empiris pada Perusahaan Otomotif yang terdaftar di Bursa Efek Indonesia. Jurnal Akuntansi. Vol. 3, No 2.

Dwiyanthi, Novia dan Gede Merta Sudiartha.2017. Pengaruh Likuiditas dan Perputaran Modal Kerja terhadap Profitabilitas pada Perusahaan Manufaktur 
Sektor Industri Barang Konsumsi.E-Jurnal Manajemen Universutas Udayana.Vol. 6, No. 9.

Felany, Indah Ayu dan Saparila Worokinasih. 2018. Pengaruh Perputaran Modal Kerja, Leverage, dan Likuiditas terhadap Profitabilitas: Studi pada Perusahaan Sub Sektor Makanan dan Minuman yang terdaftar di Bursa Efek Indonesia pada Tahun 2012-2016. Jurnal Administrasi Bisnis. Vol. 58, No 2.

Ghozali, Imam. 2016. Aplikasi Analisis Multivariete dengan Program IBM SPSS 23. Badan

Penerbit Universitas Diponegoro, Semarang.

Hery. 2016. Analisis Laporan Keuangan. PT Grasindo, Jakarta.

Kasmir. 2017. Pengantar Manajemen Keuangan. Kencana, Jakarta.

Kasmir. 2018. Analisis Laporan Keuangan. PT RajaGrafindo Persada, Depok.

Novita, Bunga Asri dan Sofie.2015. Pengaruh Struktur Modal dan Likuiditas terhadap Profitabilitas.e-Jurnal Akuntansi Trisakti. Vol. 2, No. 1.

Permana, W. S. (2020). ANALISIS PENGARUH TERPAAN IKLAN TELEVISI TERHADAP KEPUTUSAN PEMBELIAN MINUMAN BIG COLA. JURNAL EKBIS: ANALISIS, PREDIKSI DAN INFORMASI, 21(1), 91-96.

Prabowo, P. A. (2020). ANALISA PERILAKU KONSUMEN JASA KATERING UNTUK KEPERLUAN PESTA DI SURABAYA. JURNAL EKBIS: ANALISIS, PREDIKSI DAN INFORMASI, 21(1), 69-90.

Rachminiar, Erna Siti dan Khairunnisa. 2018. Pengaruh Perputaran Modal Kerja dan Likuidas terhadap Profitabilitas. e-Proceding of Management. Vol. 5, No. 3.

Rohmawati, Siti. 2017. Pengaruh Perputaran Modal Kerja, Likuiditas, dan Penjualan terhadap Profitabilitas (Studi Pada Perusahaan Food and Baverages Yang Terdaftar di Bursa Efek Indonesia Tahun 2011-2015). Skripsi. Lamongan: Universitas Islam Lamongan.

Sugiyono.2015. Metode Penelitian Kuantitatif, Kualitatif, dan RED. Alfabeta, Bandung. Sugiyono. 2017. Statistika untuk Penelitian. Alfabeta, Bandung.

Syairozi, M. (2015). Pengaruh Faktor Eksternal (Inflasi, Bunga) Dan Faktor Internal (Bagi Hasil, Jumlah Bank) Terhadap Deposito Mudharabah Pada Perbankan Syariah Di Indonesia (Doctoral dissertation, Universitas Brawijaya).

Syairozi, M. I., \& Fattah, A. (2018). "YOUTH CREATIVE ENTERPRENEUR EMPOWERMENT (YOUTIVEE)": SOLUSI BAGI KAUM MUDA UNTUK BERKONSTRIBUSI PADA PEREKONOMIAN DAN MENGURANGI PENGANGGURAN. Jesya (Jurnal Ekonomi \& Ekonomi Syariah), 1(2), 43-55. $\underline{w w w . i d x . c o . i d}$ 